\title{
Pengaruh Kepuasan Kerja Dan Keadilan Organisasional Terhadap Keterikatan Kerja Pada Karyawan Hotel Swasta X Di Bali
}

\author{
Made Trivikrama Dewantara dan Ni Made Swasti Wulanyani \\ Program Studi Sarjana Psikologi, Fakultas Kedokteran, Universitas Udayana \\ swastiwulan@unud.ac.id
}

\begin{abstract}
Abstrak
Seorang karyawan yang sudah merasa terikat dengan pekerjaannya akan memiliki motivasi bekerja yang lebih tinggi, kinerja yang lebih baik, dapat mengembangkan dirinya serta jabatan yang dimilikinya, dan cenderung loyal terhadap perusahaan tempatnya bekerja. Hal-hal tersebut dapat memberikan dampak positif terhadap kinerja perusahaan. Keterikatan kerja karyawan dapat dibentuk oleh faktor-faktor yang terjadi di lingkungan perusahaan seperti perlakuan adil dan setara yang didapat dari perusahaan dan sikap atau perasaan berdasarkan penilaian karyawan terhadap pekerjaannya. Tujuan dari penelitian ini adalah untuk mengetahui pengaruh kepuasan kerja dan keadilan organisasional terhadap keterikatan kerja karyawan Hotel Swasta X di Bali. Subjek dalam penelitian ini adalah 115 orang karyawan Hotel Swasta X di Bali. Alat ukur yang digunakan dalam penelitian ini adalah Skala Kepuasan Kerja, Skala Keadilan Organisasional dan Skala Keterikatan Kerja. Teknik analisis data yang dilakukan dalam penelitian ini adalah regresi berganda. Hasil uji regresi berganda menunjukkan nilai koefisien regresi sebesar 0,821 , nilai koefisien determinasi sebesar 0,675, nilai signifikansi sebesar 0,000 ( $<<0,05)$, nilai koefisien beta terstandarisasi variabel Kepuasan Kerja sebesar 0,363 dan nilai koefisien beta terstandarisasi variabel Keadilan Organisasional sebesar 0,502. Hasil ini menunjukkan bahwa kepuasan kerja dan keadilan organisasional berpengaruh dalam meningkatkan tingkat keterikatan kerja karyawan. Keadilan organisasional memiliki pengaruh yang lebih besar dalam meningkatkan tingkat keterikatan kerja dibandingkan dengan kepuasan kerja.
\end{abstract}

Kata kunci: kepuasan kerja, keadilan organisasional, karyawan hotel, keterikatan kerja.

\begin{abstract}
An employee who has felt engaged to his job will have a higher working motivation, better performance, can develop himself and the position he has, and tend to be loyal to the company where he works. These things can have a positive impact on company performance. Work engagement can be shaped by factors that occur in the company's environment such as fair and equal treatment obtained from the company and factors such as the attitude or feeling based on how employees feel about their job. This study aims to determine the impact of job satisfaction and organizational justice on the work engagement of employees of the Private Hotel X in Bali. Subjects in this study are 115 employees of Private Hotel X in Bali. The measuring instrument used in The study is Job Satisfaction Scale, Organizational Justice Scale and Work Engagement Scale. The data analysis technique was done using multiple regression technique. The results of multiple regression test showed regression coefficient value is 0.821 , the coefficient of determination value is 0.675 , the significance value of $0.000(\mathrm{p}<0.05)$, the standardized beta coefficient value of Job Satisfaction is 0.363 and standardized beta coefficient value of organizational justice is 0.502 . The result indicating that job satisfaction and organizational justice have an effect on increasing the level of employee's work engagement. Organizational justice has a greater impact in increasing the level of work engagement compared to job satisfaction.
\end{abstract}

Key words: job satisfaction, organizational justice, hotel employee, work engagement. 


\section{LATAR BELAKANG}

Sebuah perusahaan atau industri baik yang bekerja pada bidang penyediaan barang atau jasa pasti melibatkan tenaga kerja yang berada dalam bidang-bidang atau departemendepartemen tertentu yang pastinya dengan jumlah yang tidak sedikit. Menurut Undang-Undang Nomor 13 Tahun 2003 Bab 1 Pasal 1 ayat 2 tentang ketenagakerjaan menyebutkan bahwa tenaga kerja adalah setiap orang laki-laki atau wanita yang sedang dalam dan atau akan melakukan pekerjaan, baik di dalam maupun di luar hubungan kerja guna menghasilkan barang atau jasa untuk memenuhi kebutuhan masyarakat. Tenaga kerja tersebut atau yang selanjutnya disebut karyawan merupakan pusat dari aktivitas-aktivitas di dalam sebuah perusahaan.

Bali sebagai salah satu daerah yang mengandalkan sektor pariwisata dalam pengembangannya, melibatkan berbagai macam industri pariwisata seperti industri perhotelan, industri transportasi dan lain-lain. Menurut Badan Pusat Statistik (BPS) Provinsi Bali, kedatangan wisatawan mancanegara (wisman) ke Bali pada tahun 2017 mencapai angka 5.697.793 kunjungan. Menurut data tersebut, jumlah wisman ke Bali pada tahun 2017 naik $15.62 \%$ jika dibandingkan dengan jumlah kunjungan wisman ke Bali pada tahun 2016, dan lebih tinggi 23,14 \% jika dibandingkan dengan jumlah kunjungan wisman ke Bali pada tahun 2015. Kunjungan wisatawan dengan angka yang tinggi tersebut mengakibatkan jumlah hotel di Bali terus meningkat dari tahun ke tahun dengan jumlah hotel berbintang sebanyak 227 hotel pada tahun 2013, 249 hotel pada tahun 2014, dan 281 hotel pada tahun 2015. Tingkat Penghunian Kamar (TPK) pada hotel berbintang bulan Desember 2016 mencapai rata-rata 60,08\%.

Kunjungan wisatawan yang terus meningkat tersebut mengharuskan industri-industri pariwisata di Bali untuk terus mengembangkan asetnya agar dapat bertahan dan bersaing. Dalam sebuah industri terdapat banyak aset, seperti ilmu pengetahuan, nilai-nilai lokal, nilai-nilai global, serta modal manusia (human capital). Aset-aset tersebut merupakan modal yang harus dipertahankan dan dikembangkan, bahkan aset-aset tersebut dapat dikatakan sebagai kekayaan masa depan sebuah perusahaan (Davis \& Meyer, dalam Suwarjo, 2006; Olaniyan $\&$ Okemakinde, 2008). Sesuai dengan pernyataan sebelumnya, dapat dikatakan bahwa pengelolaan terhadap sumber daya manusia atau karyawan yang ada di dalam perusahaan merupakan salah satu hal yang dapat dilakukan untuk meningkatkan kinerja perusahaan tersebut.

Pengelolaan terhadap sumber daya manusia dalam perusahaan merupakan hal yang penting. Pernyataan tersebut sesuai dengan hasil penelitian yang dilakukan oleh Ellitan (2004) yang menyatakan bahwa sumber daya manusia dalam perusahaan memerlukan pengelolaan yang efektif dengan cara yang benar agar dapat menghasilkan sebuah kompetensi bagi perusahaan tersebut. Penelitian yang dilakukan oleh Bakker dan Leiter (2010) juga menunjukkan bahwa pengelolaan sumber daya manusia dalam perusahaan seperti penyediaan otonomi, dukungan sosial, dan kesempatan pengembangan diri yang baik dalam perusahaan dilakukan agar pada akhirnya karyawan dapat menumbuhkan sikap loyal terhadap perusahaan tempatnya bekerja dan meningkatkan keterikatan kerjanya.

\section{METODE PENELITIAN}

\section{Variabel dan Definisi Operasional}

Variabel bebas dalam penelitian ini adalah kepuasan kerja dan keadilan organisasional. Variabel terikat yang digunakan dalam penelitian ini adalah keterikatan kerja. Definisi operasional dari masing-masing variabel dalam penelitian ini adalah sebagai berikut:

\section{Keterikatan Kerja}

Keterikatan kerja pada penelitian ini adalah tingkat keterikatan antara karyawan dengan pekerjaannya yang dicirikan dengan adanya energi yang tinggi, pengabdian, dan dedikasi selama karyawan tersebut bekerja. Dalam penelitian ini, tingkat keterikatan kerja karyawan diukur dengan menggunakan skala keterikatan kerja. Semakin tinggi skor total yang diperoleh dari skala, berarti semakin tinggi keterikatan kerja yang dimiliki oleh karyawan.

\section{Kepuasan Kerja}

Kepuasan kerja dalam penelitian ini adalah pandangan seorang karyawan terhadap pekerjaannya, pandangan tersebut dilakukan dengan cara memberikan penilaian yang bersifat afektif terhadap kondisi kepuasan dirinya terhadap pekerjaannya yang meliputi gaji, promosi jabatan, pengawasan dari atasan, hubungan dengan rekan kerja, dan pekerjaan itu sendiri. Dalam penelitian ini, variabel Kepuasan Kerja diukur dengan menggunakan skala Kepuasan Kerja. Semakin tinggi skor total yang didapat dari skala, maka semakin tinggi tingkat kepuasan kerja.

Keadilan Organisasional

Keadilan organisasional pada penelitian ini adalah bagaimana persepsi positif karyawan terhadap penerapan keadilan dalam perusahaannya dalam bidang pembagian hasil, perencanaan dan penyelenggaraan prosedur, juga interaksi antar individu dalam perusahaan yang adil. Keadilan organisasional dalam penelitian ini diukur dengan menggunakan skala keadilan organisasional. Semakin tinggi skor total yang diperoleh, berarti semakin tinggi keadilan organisasional.

\section{Subjek}

Populasi dalam penelitian ini adalah seluruh karyawan Hotel Swasta X di Bali yang berjumlah 245 orang. Sampel pada penelitian ini diambil dari populasi yaitu karyawan tetap Hotel Swasta X di Bali, bekerja aktif dan tidak sedang menjalani cuti. Jumlah sampel minimal yang digunakan dalam penelitian ini adalah 115 orang. Teknik pengambilan sampel pada penelitian ini menggunakan teknik non-probability sampling dengan jenis consecutive sampling.

\section{Tempat dan Waktu Penelitian}

Penelitian ini dilaksanakan pada tanggal 7 Juli 2018, dimana sebelumnya peneliti telah memberikan surat izin penelitian kepada pihak Hotel Swasta X di Bali sekaligus menjelaskan maksud dan manfaat penelitian pada tanggal 25 Juni 2018. Penyebaran kuesioner kepada karyawan dilakukan melalui Departemen Personalia Hotel Swasta X di Bali. Skala yang disebarkan terdiri atas informed consent, skala kepuasan kerja, skala keadilan organisasional, dan skala keterikatan kerja. Skala yang disebarkan berjumlah total 115 buah skala yang seluruhnya layak untuk dianalisis. 


\section{Alat Ukur}

Teknik pengumpulan data pada penelitian ini adalah menggunakan kuesioner. Terdapat tiga jenis kuesioner didistribusikan kepada responden dengan tujuan untuk mendapatkan respon terkait kepuasan kerja, keadilan organisasional, dan keterikatan kerja pada subjek penelitian. Dalam pengukurannya, tingkat tanggapan responden terhadap setiap butir pertanyaan didasarkan pada pengembangan Skala Likert. Tanggapan responden terhadap kuesioner diberi skor dalam 4 poin Skala Likert yaitu; (1) Skor 4 jika dinilai Sangat Setuju; (2) Skor 3 jika dinilai Setuju; (3) Skor 2 jika dinilai Tidak Setuju; dan (4) Skor 1 jika dinilai Sangat Tidak Setuju.

Alat ukur yang valid dan reliabel merupakan syarat untuk mampu memberikan informasi dan hasil data yang akurat. Pengukuran terhadap validitas ini dilakukan dengan professional judgement oleh para pakar dalam bidang psikologi dengan tujuan memastikan aitem-aitem dalam alat ukur telah sesuai dengan indikator perilaku yang hendak diukur. Pengujian terhadap validitas konstruk dilakukan dengan seleksi terhadap aitem-aitem dalam skala berdasarkan nilai korelasi aitem-total. Koefisien korelasi aitem-total yang memiliki nilai lebih besar atau sama dengan 0,30 dianggap sudah memuaskan (Cronbach dalam Azwar, 2015). Sedangkan, reliabilitas dari suatu skala dapat dikatakan baik jika memiliki nilai koefisien alpha lebih besar dari 0,60.

Dari hasil uji validitas skala kepuasan kerja memiliki koefisien korelasi aitem-total berkisar antara 0,594 sampai 0,802. Hasil uji validitas skala keadilan organisasional memiliki koefisien korelasi aitem-total berkisar antara 0,429 sampai 0,869. Hasil uji validitas skala keterikatan kerja memiliki koefisien korelasi aitem-total berkisar antara 0,376 sampai 0,626.

Hasil uji reliabilitas skala kepuasan kerja dengan menggunakan teknik Cronbach Alpha menunjukkan koefisian alpha $(\alpha)$ adalah 0,938 yang memiliki arti bahwa skala kepuasan kerja mampu mencerminkan 93,8\% variasi skor murni subjek. Hasil uji reliabilitas skala keadilan organisasional dengan menggunakan teknik Cronbach Alpha menunjukkan koefisian alpha $(\alpha)$ adalah 0,943. Hasil uji reliabilitas skala keterikatan kerja dengan menggunakan teknik Cronbach Alpha menunjukkan koefisian alpha $(\alpha)$ adalah 0,897 .

\section{Teknik Analisis Data}

Sebelum melakukan uji hipotesis data penelitian maka perlu dilakukan uji asumsi terlebih dahulu seperti uji normalitas, uji linearitas, uji multikolinearitas dan uji heteroskedastisitas. Uji normalitas dilakukan untuk menguji apakah data uji mempunyai distribusi normal atau tidak. Pengujian ini menetapkan apakah skor-skor dalam sampel dapat secara masuk akal dianggap berasal dari populasi tertentu dengan distribusi normal ataupun tidak (Utama, 2016). Uji normalitas data penelitian dilakukan dengan uji Kolmogorov-Smirnov. Uji linearitas dilakukan untuk mengetahui apakah terdapat hubungan yang linear atau tidak antara kedua variabel penelitian, yaitu antara skor variabel bebas dan variabel terikat menunjuk garis sejajar atau tidak (Sugiyono, 2014). Uji linearitas data penelitian dilakukan dengan menggunakan analisis compare mean, lalu menggunakan test of linearity. Uji multikolineartitas berguna untuk menguji apakah dalam model regresi ditemukan adanya kolerasi antar variabel bebas. Uji multikolinearitas dilakukan dengan melihat nilai dari Variance Inflation Factor (VIF) dan nilai Tolerance. Uji heteroskedastisitas digunakan untuk menguji apakah dalam model regresi terjadi ketidaksamaan varians dari residual satu pengamatan ke pengamatan yang lain. Uji heteroskedastisitas dilakukan dengan uji Glejser. Pengujian hipotesis penelitian dapat dilakukan setelah semua uji asumsi terpenuhi. Uji hipotesis pada penelitian ini menggunakan teknik uji regresi berganda. Analisis data penelitian ini dilakukan dengan bantuan perangkat lunak SPSS 20.0 release for Windows.

\section{HASIL PENELITIAN}

\section{Karakteristik Subjek}

Subjek dalam penelitian ini adalah karyawan Hotel Swasta X di Bali yang berjumlah 115 orang karyawan yang terdiri dari 79 orang laki-laki dan 36 orang perempuan. Mayoritas subjek yang terlibat dalam penelitian ini berusia antara 41 tahun sampai 50 tahun yang berjumlah 46 orang dengan persentase sebesar $40,0 \%$. Mayoritas subjek bekerja selama 16 sampai dengan 20 tahun yang berjumlah 54 orang dengan persentase sebesar $47,0 \%$.

\section{Deskripsi Data Penelitian}

Rangkuman hasil deskripsi data dalam penelitian ini dapat dilihat dalam tabel 1. (Deskripsi Data Penelitian. Terlampir). Hasil deskripsi pada tabel 1 menunjukkan bahwa variabel kepuasan kerja memiliki nilai mean empiris yang berbeda secara signifikan terhadap mean teoretisnya. Hal ini dapat dilihat dari nilai probabilitas sebesar 0,000 yang lebih kecil dari taraf signifikansi yang digunakan yaitu 5\% atau 0,05 (p $<\alpha$ ). Hasil nilai t menunjukkan nilai positif yang memiliki arti bahwa mean empiris variabel kepuasan kerja lebih besar dari mean teoretisnya. Tabel 1 juga menunjukkan bahwa variabel keadilan organisasional memiliki nilai mean empiris yang berbeda secara signifikan terhadap mean teoretisnya. Hal ini dapat dilihat dari nilai probabilitas sebesar 0,000 yang lebih kecil dari taraf signifikansi yang digunakan yaitu 5\% atau 0,05 $(\mathrm{p}<\alpha)$. Hasil nilai t menunjukkan nilai positif yang memiliki arti bahwa mean empiris variabel keadilan organisasional lebih besar dari mean teoretisnya. Tabel 1 juga menunjukkan bahwa variabel keterikatan kerja memiliki nilai mean empiris yang berbeda secara signifikan terhadap mean teoretisnya. Hal ini dapat dilihat dari nilai probabilitas sebesar 0,000 yang lebih kecil dari taraf signifikansi yang digunakan yaitu 5\% atau $0,05(\mathrm{p}<\alpha)$. Hasil $\mathrm{t}$ hitung menunjukkan nilai positif yang memiliki arti bahwa mean empiris variabel keterikatan kerja lebih besar dari mean teoretisnya.

\section{Uji Asumsi \\ Uji Normalitas}

Uji normalitas pada penelitian ini menggunakan perangkat lunak SPSS 20.0 for Windows. Berdasarkan hasil uji normalitas pada tabel 2 (hasil uji normalitas data penelitian. terlampir) menunjukkan bahwa sebaran data pada variabel kepuasan kerja berdistribusi normal dengan nilai KolmogorovSmirnov 1,149 dan nilai signifikansi 0,143 ( $p>0,05)$. Hasil uji 
normalitas pada tabel 2 juga menunjukkan bahwa sebaran data pada variabel keadilan organisasional berdistribusi normal dengan nilai Kolmogorov- Smirnov 1,166 dan nilai signifikansi 0,132 ( $>>0,05)$. Tabel 2 juga menunjukkan bahwa sebaran data pada variabel keterikatan kerja berdistribusi normal dengan nilai Kolmogorov- Smirnov 0,878 dan signifikansi 0,423 ( $>>0,05)$.

Uji Linearitas

Uji linearitas pada penelitian ini dilakukan menggunakan perangkat lunak SPSS 20.0 for Windows. Berdasarkan hasil uji linearitas pada tabel 3 (hasil uji linearitas data penelitian. terlampir) menunjukkan bahwa terdapat hubungan yang linear antara variabel kepuasan kerja dengan variabel keterikatan kerja, serta antara variabel keadilan organisasional dengan keterikatan kerja. Hal ini ditunjukkan melalui nilai taraf signifikansi linearity antara variabel kepuasan kerja dan variabel keterikatan kerja yaitu sebesar 0,000 $(\mathrm{p}<0,05)$ dan memiliki nilai taraf signifikansi deviation from linearity sebesar $0,125(p>0,05)$, serta nilai taraf signifikansi linearity antara variabel keadilan organisasional dan variabel keterikatan kerja yaitu sebesar $0,000(\mathrm{p}<0,05)$ dan memiliki nilai taraf signifikansi Deviation from Linearity sebesar 0,442 $(\mathrm{p}>0,05)$.

Uji Multikolinearitas

Uji multikolinearitas pada penelitian ini menggunakan perangkat lunak SPSS 20.0 for Windows. Berdasarkan hasil uji multikolinearitas pada tabel 4 (hasil uji multikolienaritas data penelitian. terlampir) menunjukkan bahwa kedua variabel penelitian yaitu kepuasan kerja dan keadilan organisasional tidak terjadi multikolinearitas atau tidak terjadi korelasi. Hal ini ditunjukkan berdasarkan pada variabel kepuasan kerja dan keadilan organisasional yang sama-sama menunjukkan nilai Tolerance sebesar 0,361 (Tolerance $>0,1$ ) dan nilai Variance Inflation Factor (VIF) sebesar 2,769 (VIF<10).

\section{Uji Heteroskedastisitas}

Uji heteroskedastisitas pada penelitian ini menggunakan perangkat lunak SPSS 20.0 for Windows. Berdasarkan hasil uji heteroskedastisitas pada tabel 5 (hasil uji heteroskedastisitas data penelitian. terlampir) menunjukkan bahwa kedua variabel penelitian yaitu kepuasan kerja dan keadilan organisasional tidak terjadi heteroskedastisitas. Hal ini ditunjukkan berdasarkan pada variabel kepuasan kerja memiliki nilai signifikansi $0,380(\mathrm{p}>0,05)$, serta pada variabel keadilan organisasional juga menunjukkan nilai signifikansi lebih besar dari 0,05 ( $\mathrm{p}>0,05)$, yaitu sebesar 0,062 .

\section{Uji Hipotesis}

Uji hipotesis statistik yang digunakan dalam penelitian ini adalah uji regresi berganda (Multiple Regression) dengan menggunakan bantuan perangkat lunak SPSS 20.0 for Windows.

Berdasarkan hasil uji regresi berganda pada tabel 6 (uji regresi berganda signifikansi nilai $f$. terlampi) menunjukkan bahwa nilai $F$ hitung bernilai sebesar 116,116 dengan taraf signifikansi sebesar 5\% atau 0,05. Tabel 6 ini juga menunjukkan nilai signifikansi sebesar $0,000 \quad(\mathrm{p}<0,05)$, sehingga dapat disimpulkan bahwa $\mathrm{HO}$ ditolak dan Ha pada hipotesis mayor dalam penelitian ini diterima. Jadi, terdapat pengaruh kepuasan kerja dan keadilan organisasional terhadap keterikatan kerja pada subyek penelitian.

Berdasarkan hasil pada tabel 7 (besarnya pengaruh variabel bebas terhadap variabel terikat. terlampir) menunjukkan nilai $\mathrm{R}$ sebesar 0,821, hal ini menunjukkan bahwa terdapat pengaruh yang kuat antara variabel bebas yaitu kepuasan kerja dan keadilan organisasional terhadap variabel terikat yaitu keterikatan kerja. Nilai koefisien determinasi ( $\mathrm{R}$ Square) sebesar 0,675 yang menunjukkan bahwa variabel bebas memiliki pengaruh sebesar $67,5 \%$ terhadap variabel terikat, sedangkan variabel yang tidak diteliti memiliki pengaruh sebesar $32,5 \%$ terhadap variabel terikat.

Berdasarkan hasil pada tabel 8 (hasil uji regresi berganda nilai koefisien beta dan nilai $t$ variabel kepuasan kerja dan keadilan organisasional terhadap keterikatan kerja. terlampir) menunjukkan variabel kepuasan kerja memiliki koefisien beta terstandarisasi sebesar 0,363 , nilai $\mathrm{T}$ sebesar 4,045 dan taraf signifikansi sebesar 0,000 ( $\mathrm{p}<0,05)$, berdasarkan hasil tersebut dapat dikatakan bahwa kepuasan kerja memiliki pengaruh secara signifikan dalam meningkatkan tingkat keterikatan kerja. Variabel keadilan organisasional memiliki koefisien beta terstandarisasi sebesar 0,502, nilai $\mathrm{T}$ sebesar 5,596 dan taraf signifikansi sebesar $0,000(\mathrm{p}<0,05)$, berdasarkan nilai tersebut dapat dikatakan bahwa keadilan organisasional berpengaruh secara signifikan dalam meningkatkan tingkat keterikatan kerja karyawan.

Variabel kepuasan kerja memiliki nilai koefesien beta terstandarisasi yang bernilai 0,363 , sedangkan pada variabel keadilan organisasional memiliki nilai koefesien beta terstandarisasi yang bernilai 0,502. Koefesien beta terstandarisasi digunakan untuk membandingkan variabel bebas, sehingga dapat diketahui variabel bebas manakah yang memiliki pengaruh yang lebih dominan terhadap variabel terikat. Nilai positif yang ditunjukkan memiliki arti bahwa variabel bebas memiliki pengaruh dalam meningkatkan tingkat variabel terikat. Variabel keadilan organisasional memiliki nilai koefesien beta terstandarisasi yang lebih besar dibandingkan dengan variabel kepuasan kerja. Jadi, variabel keadilan organisasional memiliki pengaruh yang lebih besar dalam meningkatkan tingkat keterikatan kerja dibandingkan dengan kepuasan kerja.

Rumus garis regresi berganda yang digunakan dalam penelitian ini adalah

$$
\begin{aligned}
& \text { Y=17,964 }+0,469 \mathrm{X} 1+0,521 \mathrm{X} 2 \\
& \text { Keterangan: } \\
& \begin{array}{ll}
\mathrm{Y} & =\text { Keterikatan kerja } \\
\mathrm{X} 1 & =\text { Kepuasan kerja } \\
\mathrm{X} 2 & =\text { Keadilan organisasional }
\end{array}
\end{aligned}
$$

Garis regresi tersebut memiliki arti sebagai berikut:

(1) Konstanta sebesar 17,964 menunjukkan bahwa jika variabel kepuasan kerja dan keadilan organisasional memiliki nilai 0 , maka nilai keterikatan kerja yang dimiliki akan sebesar 17,964. (2) Koefesien regresi X1 sebesar 0,469. Nilai positif yang ditunjukkan memiliki arti bahwa variabel bebas memiliki 
pengaruh dalam meningkatkan tingkat variabel terikat. Jadi, setiap terjadi peningkatan satuan nilai dari variabel kepuasan kerja, maka nilai variabel keterikatan kerja juga akan mengalami peningkatan sebesar 0,469. (3) Koefesien regresi $\mathrm{X} 2$ sebesar 0,521. Nilai positif yang ditunjukkan memiliki arti bahwa variabel bebas memiliki pengaruh dalam meningkatkan tingkat variabel terikat. Jadi, setiap terjadi peningkatan satuan nilai dari variabel keadilan organisasional, maka nilai variabel keterikatan kerja juga akan mengalami peningkatan sebesar 0,521 .

Rangkuman hasil uji hipotesis mayor dan hipotesis minor pada penelitian ini dapat dilihat pada tabel 9 (rangkuman hasil uji hipotesis penelitian. terlampir).

\section{PEMBAHASAN DAN KESIMPULAN}

\section{Pembahasan}

Berdasarkan hasil uji hipotesis, hipotesis mayor dalam penelitian ini diterima, yang berarti variabel kepuasan kerja dan variabel keadilan organisasional memiliki pengaruh yang signifikan terhadap variabel keterikatan kerja pada subjek penelitian. Nilai tingkat keterikatan kerja karyawan pada penelitian ini dipengaruhi oleh variabel kepuasan kerja dan keadilan organisasional. Uji statistik juga menunjukkan hasil nilai $\mathrm{R}$ sebesar 0,821 yang berarti terdapat pengaruh yang kuat antara variabel kepuasan kerja dan keadilan organisasional terhadap keterikatan kerja. Adanya pengaruh kepuasan kerja dan keadilan organisasional terhadap keterikatan kerja sesuai dengan pendapat yang disampaikan oleh Schaufeli dan Bakker (2010) yang menyatakan bahwa tingkat keterikatan kerja seorang karyawan dapat dipengaruhi oleh faktor-faktor terkait lingkungan kerja seperti motivasi kerja, kepuasan kerja, peraturan dalam perusahaan, dan adanya keadilan atau kelayakan dalam sebuah perusahaan. Penelitian yang dilakukan oleh Yeh (2013) yang menyatakan bahwa keterikatan kerja karyawan dipengaruhi secara signifikan oleh kepuasan yang dimilikinya terhadap pekerjaannya, dimana karyawan dengan tingkat keterikatan yang tinggi akan cenderung memiliki komitmen afektif yang tinggi juga terhadap pekerjaannya.

Schaufeli dan Bakker (2010) menyatakan bahwa tedapat tiga faktor utama yang dapat memengaruhi keterikatan kerja yang dimiliki oleh seorang karyawan. Faktor pertama adalah sumber daya pribadi (personal resources) termasuk di dalamnya aspek-aspek individual atau aspek dalam diri seorang individu seperti efikasi diri. Faktor kedua adalah sumber daya kerja (job resources). Sumber daya kerja merupakan faktor luar diri atau faktor eksternal yang dapat memengaruhi keterikatan kerja karyawan, dalam penelitian ini faktor yang dapat dikatakan sebagai sumber daya kerja adalah situasi fisik dan sosial yang dimiliki oleh subjek penelitian termasuk didalamnya fasilitas yang diberikan oleh perusahan kepada karyawannnya untuk melakukan pekerjaan, peraturanperaturan dalam perusahaan, kondisi lingkungan sosial termasuk hubungan antara atasan dan bawahan juga antar rekan kerja, dan pemberian hasil pekerjaan atau gaji. Faktor ketiga adalah tuntutan pekerjaan (job demands). Tuntutan pekerjaan adalah hal-hal apa saja yang diperlukan oleh karyawan untuk melakukan pekerjaannya, dimana dapat berupa tuntutan yang bersifat fisiologis maupun tuntutan yang bersifat psikologis.

Menurut Bakker dan Demerouti (2008) sumber daya kerja merupakan sumber daya yang diberikan oleh perusahaan kepada karyawannya dengan tujuan untuk mengimbangi tuntutan pekerjaan, dimana sumber daya kerja haruslah mampu untuk mengimbangi tuntutan pekerjaan agar terjadi keseimbangan antara usaha yang diberikan karyawan dengan hasil yang diterima. Menurut Bakker et al (2008) ketidakseimbangan antara sumber daya kerja dengan tuntutan pekerjaan dapat menyebabkan terjadinya kelelahan bagi karyawan dan timbulnya perilaku yang merugikan bagi organisasi dan perusahaan. Pendapat Bakker et al (2008) tersebut sesuai dengan penelitian yang dilakukan oleh Rothmann (2008) yang menyebutkan bahwa kelelahan yang dialami oleh seorang karyawan dapat memicu terjadinya penarikan diri secara psikologis oleh karyawan terhadap pekerjaan yang diberikan kepadanya, dimana menurut Rothman (2008) penarikan diri tersebut terjadi akibat dari adanya mekanisme adaptasi untuk mengatasi tuntutan pekerjaan yang berlebihan.

Koefisien determinasi (R Square) yang ditunjukkan dalam penelitian ini memiliki nilai sebesar 0,675 yang berarti variabel kepuasan kerja dan keadilan organisasional secara bersama-sama memiliki pengaruh sebesar $67,5 \%$ terhadap keterikatan kerja pada subjek penelitian, sedangkan variabel lain yang tidak diteliti dalam penelitian ini memengaruhi variabel keterikatan kerja sebesar 32,5\%. Berdasarkan nilai $\mathrm{R}$ square tersebut, kepuasan kerja dan keadilan organisasional dapat dikatakan memiliki pengaruh yang kuat terhadap keterikatan kerja yang dimiliki oleh subjek penelitian.

Hasil analisis penelitian menunjukkan bahwa variabel kepuasan kerja dapat dikatakan memiliki pengaruh yang signifikan untuk meningkatkan tingkat keterikatan kerja yang dimiliki oleh subjek penelitian. Hasil analisis tersebut sesuai dengan penelitian yang dilakukan oleh Ludviga dan Kalvina (2015), yang menyatakan bahwa kepuasan kerja yang dimiliki oleh seorang karyawan merupakan komponen yang memengaruhi keterikatan kerja dengan nilai koefisien yang paling tinggi dan memiliki pengaruh yang signifikan untuk meningkatkan keterikatan kerja. Pernyataan serupa juga disampaikan oleh Trinrud (2015) yang menyatakan bahwa rasa keterikatan yang tumbuh antara seorang pekerja dengan pekerjaan yang dimilikinya merupakan hasil pengaruh dari kepuasan yang didapat dari pekerjaannya. Schaufeli dan Bakker (2010) juga menyebutkan bahwa terdapat faktor individu atau personal yang dapat memengaruhi keterikatan kerja, faktor tersebut dapat berupa aspek afektif, dimana kepuasan terhadap pekerjaan merupakan salah satu variabel yang dapat memengaruhi aspek afektif seorang karyawan.

Pada karyawan dengan tingkat kepuasan kerja yang tinggi, ia akan menunjukkan rasa puas terhadap aspek-aspek dalam pekerjaannya. Aspek-aspek tersebut adalah sesuainya kemampuan yang dimiliki dengan kemampuan yang diperlukan dalam melakukan pekerjaan yang dimiliki, adanya 
dukungan dari atasan, rekan kerja yang mendukung pekerjaan, jenjang promosi jabatan yang tersedia, dan gaji yang didapat dirasa sesuai dengan beban kerja yang didapatkan (Hartatik, 2014

Kategorisasi terhadap skor dalam skala kepuasan kerja dalam penelitian ini menunjukkan bahwa 78,2\% subyek memiliki skor kepuasan kerja dalam kategori yang sangat tinggi, berdasarkan hasil kategorisasi skor tersebut dapat dikatakan bahwa mayoritas subyek dalam penelitian ini memiliki kepuasan kerja yang sangat tinggi. Nilai kepuasan kerja yang sangat tinggi berarti subjek penelitian memiliki penilaian afektif yang sangat baik terhadap pekerjaannya dan dapat dikatakan bahwa pekerjaan yang dimiliki oleh subjek penelitian saat ini telah memenuhi harapannya terkait dengan aspek-aspek kepuasan kerja yang telah dijelaskan sebelumnya.

Hasil analisis terhadap data dalam penelitian ini menunjukkan bahwa variabel keadilan organisasional memiliki pengaruh yang signifikan terhadap keterikatan kerja pada subyek dalam penelitian ini. Temuan yang disebutkan sebelumnya didukung oleh penelitian yang dilakukan oleh Inoue et al (2010) yang menyebutkan bahwa terdapat pengaruh yang signifikan antara dimensi dalam keadilan organisasional terhadap keterikatan kerja karyawan, dimana keadilan distribusional dan keadilan interaksional yang merupakan dimensi dari keadilan organisasi dinyatakan memiliki pengaruh yang positif terhadap keterikatan kerja dengan memberikan peningkatan terhadap sumber daya kerja. Temuan tersebut juga didukung oleh penelitian yang dilakukan oleh Lyu (2016) yang menyatakan bahwa terdapat pengaruh yang positif antara keadilan dalam organisasi dan keterikatan kerja karyawan, dimana disebutkan bahwa keadilan organisasional secara keseluruhan dapat dilihat sebagai sumber daya eksternal yang memengaruhi keterikatan kerja.

Teori pertukaran sosial oleh Saks (dalam Hassan, 2014) menyatakan bahwa adanya hubungan timbal balik antara karyawan dan organisasi atau perusahaan tempatnya bekerja terkait dengan pemberian sumberdaya secara timbal balik, dimana Saks menyatakan bahwa karyawan akan mengembangkan keterikatan terhadap pekerjaannya dengan tingkat yang sebanding dengan sumber daya yang ia terima dari perusahaan. Teori pertukaran sosial juga menjelaskan bahwa ketika seorang karyawan merasa bahwa dirinya mendapatkan perlakuan adil dari perusahaan maka karyawan tersebut juga akan memberikan perlakuan yang baik terhadap perusahaan dengan meningkatkan kinerjanya yang mengarah kepada timbulnya rasa keterikatan (Law, 2015). Penelitian yang dilakukan oleh Ozer (2017) juga mendukung adanya pengaruh keadilan organisasional terhadap keterikatan kerja karyawan, dimana menurut Ozer (2017) persepsi yang baik terhadap adanya keadilan dalam organisasi secara statistik terbukti meningkatkan tingkat keterikatan kerja karyawan.

Berdasarkan hasil pengujian statistik terhadap variabel penelitian, didapatkan nilai koefisien beta terstandarisasi dari masing-masing variabel bebas. Berdasarkan nilai koefisien beta terstandarisasi yang dihasilkan, variabel keadilan organisasional memiliki nilai yang lebih besar jika dibandingkan dengan nilai yang dimiliki oleh variabel kepuasan kerja, nilai tersebut berarti dalam penelitian ini variabel keadilan organisasional memiliki pengaruh yang lebih besar terhadap keterikatan kerja subyek. Berdasarkan pernyataan sebelumnya dapat dikatakan bahwa subjek penelitian lebih mementingkan adanya aplikasi dari keadilan dalam organisasinya dalam mengembangkan keterikatan terhadap pekerjaannya. Temuan sebelumnya didukung oleh penelitian yang dilakukan oleh Yeh (2013) yang menyatakan bahwa pada industri perhotelan yang memiliki sektor bisnis berupa layanan jasa, keterikatan kerja karyawan lebih dipengaruhi oleh kondisi eksternal karyawan yaitu situasi dan kondisi di lingkungan kerjanya, dimana penerapan keadilan dalam organisasi juga termasuk didalamnya.

Kategorisasi terhadap skor dalam skala Keadilan organisasional menunjukkan bahwa $72,2 \%$ subyek memiliki skor keadilan organisasional dalam kategori sangat tinggi, dimana dapat dikatakan subyek dalam penelitian memiliki tingkat persepsi terhadap pelaksanaan keadilan dalam perusahaan dengan tingkat yang tinggi. Kategorisasi terhadap skor dalam skala keterikatan kerja menunjukkan bahwa $87 \%$ memiliki skor keterikatan kerja dengan kategori yang sangat tinggi. Berdasarkan persentase yang dihasilkan tersebut dapat dikatakan bahwa subyek dalam penelitian ini memiliki tingkat keterikatan kerja tinggi yang berarti subjek penelitian merasakan keterikatan yang tinggi dengan pekerjaan yang dimilikinya.

Data lain yang didapatkan dalam penelitian ini adalah masa bekerja dari subjek penelitian. berdasarkan kategorisasi masa bekerja karyawan didapatkan hasil bahwa 64,4\% memiliki masa kerja lebih dari 10 tahun, dimana berdasarkan penggolongan oleh Mcelroy, Morrow dan Rude (dalam Azizi, 2017), masa kerja diatas 10 tahun termasuk masa kerja yang lama, hasil tersebut juga dapat menandakan adanya loyalitas pada subjek penelitian. Pendapat tersebut didukung oleh penelitian yang dilakukan oleh Ludviga dan Kalvina (2016) yang menyatakan bahwa terdapat pengaruh yang signifikan antara keterikatan kerja dengan loyalitas yang dimiliki oleh karyawan dalam suatu perusahaan, hal tersebut juga sejalan dengan pendapat Hewitt (dalam Schaufeli, 2013) dimana karyawan yang memiliki tingkat keterikatan kerja yang tinggi akan secara konsisten menunjukkan perilaku umum yang salah satunya adalah perilaku stay atau menetap, yaitu memiliki keinginan dengan intensitas yang tinggi untuk menjadi anggota dari organisasi, walaupun terdapat kesempatan untuk meninggalkan tempat kerja. Berdasarkan pemaparan sebelumnya, dapat dikatakan bahwa tingginya tingkat keterikatan kerja, kepuasan kerja, dan keadilan organisasi yang dimiliki oleh subyek dalam penelitian ini, menumbuhkan kesetiaan kepada karyawan yang menyebabkan karyawan memilih untuk bekerja dalam waktu lama dalam perusahaannya yaitu Hotel Swasta X di Bali.

Berdasarkan pembahasan sebelumnya, dapat dinyatakan bahwa subjek penelitian memiliki keterikatan yang tinggi dengan pekerjaannya, tingkat keterikatan kerja tersebut dapat terjadi karena subjek memiliki penilaian yang positif terhadap keadilan organisasional dalam perusahannya dan memiliki 
tingkat kepuasan kerja yang tinggi. Dalam penelitian ini juga telah menunjukkan hasil bahwa kepuasan kerja dan keadilan organisasional memiliki pengaruh secara signifikan dalam meningkatkan keterikatan kerja pada subjek.

Adapun beberapa keterbatasan dalam penelitian ini adalah populasi subjek yang kurang luas, proses pengalihan bahasa alat ukur adaptasi hanya dilakukan oleh peneliti tanpa adanya bantuan tenaga yang ahli dalam bidang pengalih bahasaan, komposisi dari masing-masing alat ukur hanya terdiri dari aitem pernyataan favorable saja, dan alat ukur penelitian didistribusikan kepada subjek penelitian melalui departemen personalia Hotel Swasta X di Bali, sehingga peneliti tidak memiliki kontrol langsung atas proses pengisian alat ukur oleh subjek.

\section{Kesimpulan dan Saran}

\section{$\underline{\text { Kesimpulan }}$}

Berdasarkan hasil analisis penelitian dan pengujian hipotesis yang telah dilakukan, menghasilkan kesimpulan dari penelitian ini yaitu sebagai berikut:

1.Kepuasan kerja dan keadilan organisasional memiliki pengaruh dalam meningkatkan tingkat keterikatan kerja karyawan Hotel Swasta X di Bali.

2.Kepuasan kerja memiliki pengaruh dalam meningkatkan tingkat keterikatan kerja karyawan Hotel Swasta X di Bali.

3.Keadilan organisasional memiliki pengaruh dalam meningkatkan tingkat keterikatan kerja karyawan Hotel Swasta X di Bali.

4.Mayoritas karyawan Hotel Swasta X di Bali memiliki taraf kepuasan kerja yang sangat tinggi dengan persentase sebesar 78,2\%.

5.Mayoritas karyawan Hotel Swasta X di Bali memiliki taraf keadilan organisasional yang sangat tinggi dengan persentase sebesar $72,2 \%$.

6. Mayoritas karyawan Hotel Swasta X di Bali memiliki taraf keterikatan kerja yang sangat tinggi dengan persentase sebesar $87 \%$.

$\underline{\text { Saran }}$

Berdasarkan kesimpulan yang disebutkan sebelumnya, saran yang dapat diberikan pada pihak-pihak yang terkait dalam penelitian ini adalah:

Bagi departemen personalia hotel Hotel Swasta X di Bali.

Departemen personalia agar tetap menjaga kepuasan kerja karyawan dengan cara tetap menyediakan sumber daya kerja yang dibutuhkan karyawan dalam melakukan pekerjaannya, seperti fasilitas pendukung kerja dan imbalan yang sesuai dengan beban kerjaannya. Dan juga diharapkan untuk mempertahankan kondisi yang menimbulkan persepsi positif karyawan terhadap keadilan dalam perusahaan tetap tinggi melalui penerapan konsep keadilan dalam prosedur, pemberian gaji dan interaksi antar karyawan dalam perusahaan, karena dalam penelitian ini terbukti bahwa keterikatan kerja karyawan Hotel Swasta X di Bali lebih dipengaruhi oleh variabel keadilan organisasional.

Bagi Karyawan Hotel Swasta X di Bali.

Bagi Karyawan Hotel Swasta X di Bali disarankan untuk mempertahankan tingkat keterikatan kerja dan kepuasan kerja yang tinggi untuk tujuan keberlangsungan perusahaan dengan cara ikut serta secara aktif dalam program-program pemberdayaan karyawan yang diselenggarakan oleh pihak perusahaan seperti penyelenggaraan pelatihan dan aktivitas luar ruangan.

Bagi Peneliti Selanjutnya.

Bagi peneliti selanjutnya dapat melakukan penelitian dengan menggunakan variabel-variabel internal yang dimiliki seorang tenaga kerja seperti tipe kepribadian, efikasi diri, dan locus of control. Selanjutnya dalam proses adaptasi alat ukur diperlukan keterlibatan seseorang dengan kompetensi di bidang pengalih bahasaan khususnya orang yang memahami bahasa Inggris ilmiah. Selain itu, dibutuhkan penelitian lebih lanjut untuk mengetahui faktor-faktor yang berpengaruh terhadap tingginya tingkat perputaran karyawan diluar faktor keterikatan kerja, kepuasan kerja, dan keadilan organisasional. Penelitian selanjutnya juga dapat dilakukan dengan menggunakan subyek yang lebih luas, yaitu karyawan dari seluruh hotel yang ada di Bali, agar nantinya hasil penelitian dapat menggambarkan kondisi keterikatan kerja karyawan pada industri perhotelan di Bali dan dapat mengetahui pengaruh yang dimiliki oleh kepuasan kerja, keadilan organisasi, maupun variabel lainnya terhadap keterikatan kerja karyawan hotel di Bali.

\section{DAFTAR PUSTAKA}

Azizi, N. (2017). Pengaruh Keadilan Organisasi terhadap Employee Engagement Pada Karyawan Bank BTN KCU Medan. Jurnal Universitas Sumatera Utara.

Azwar, S. (2015). Reliabilitas dan validitas edisi 4. Yogyakarta: Pustaka Pelajar.

Badan Pusat Statistik Provinsi Bali, (2018). Laporan Perkembangan Pariwisata Bali Tahun 2018. Bali. Diakses pada 20 maret 2018

dari http://bali.bps.go.id/webbeta/website/brs_ind/brsInd20160801122411.pdf.

Bakker, A. B., \& Demerouti, E. (2008). Towards A Model of Work Engagement. Career Development International, 13(3),209. 223. Diakses melalui https://www.emeraldinsight.com/doi/abs/10.1108/1362043 0810870476 ?journalCode $=$ cd. Diakses pada tanggal $18 \mathrm{Mei}$ 2017.

Bakker, A. B., Schaufeli, W. B., Leiter, M. P., \& Taris, T. W. (2008). Work Engagement: An Emerging Concept in Occupational Health Psychology. Work and Stress, vol 22. England: Taylor \& Francis.

Bakker, A.B. \& Leiter, M.P. (2010). Where to go from here: integration and future research on work engagement. In: Bakker, A.B. dan Leiter, M.P., editor. Work engement, a handbook of essential theory and research. New York: Psychology Press.

Ellitan, L. (2004). Praktik-praktik pengelolaan sumber daya manusia dan keunggulan kompetitif berkelanjutan. Jurnal manajemen dan Kewirausahaan, 4(2), pp-65.

Hartatik, I. P. (2014). Buku Praktis Mengembangkan SDM. Yogyakarta: Laksana.

Inoue, A., Kawakami, N., Ishizaki, M., Shimazu, A., Tsuchiya, M., Tabata, M., ... \& Kuroda, M. (2010). Organizational justice, psychological distress, and work engagement in Japanese workers. International archives of occupational and environmental health, 83(1), 29. Diakses melalui https://link.springer.com/article/10.1007/s00420-009-04857. Diakses pada tanggal 17 Mei 2018. 
Kartika, R. G. W. U. (2012). Pengaruh Kepuasan Kerja Terhadap Komitmen Organisasional Pada Karyawan PT. Hellomotion Korpora Indonesia. (Skripsi tidak dipublikasikan). Universitas Indonesia. Depok.

Law, M. (2015). Employee disengagement: The impact of role discrepancy, professional identity and organizational justice. (Dissertation) Diakses Melalui https://dt.athabascau.ca/jspui/handle/10791/124. Diakses pada tanggal 17 Mei 2018.

Ludviga, I., \& Kalvina, A. (2015). Exploring the Relationships between Job Satisfaction, Work Engagement and Loyalty of Academic Staff. World Academy of Science, Engineering and Technology, International Journal of Social, Behavioral, Educational, Economic, Business and Industrial Engineering, 10(1), 99-105.

Lyu, X. (2016). Effect of organizational justice on work engagement with psychological safety as a mediator: Evidence from China. Social Behavior and Personality: an international journal, 44(8), 1359-1370.

Modrak, V., Dima, I. C., \& Man, M. (2011). Methodical approach to corporate sustainability planning. Polish Journal of Management Studies, 3, 156-166.

Olaniyan, D.A. \& Okemakinde, T., (2008). Human Capital Theory. Pakistan Journal of Social Sciences 5(5): 479-483.

Özer, Ö., Uğurluoğlu, Ö., \& Saygili, M. (2017). Effect of Organizational Justice on Work Engagement in Healthcare Sector of Turkey. Journal of Health Management, 19(1), 73-83.

Rothbard, N. P., \& Patil, S. V. (2012). Being There. In the Oxford handbook of positive organizational scholarship.

Rothmann, S. (2008). Job satisfaction, occupational stress, burnout and work engagement as components of work-related wellbeing. SA journal of industrial psychology, 34(3), 1116.

Schaufeli, W. B., Bakker, A. B. (2010). Defining and measuring work engagement: Bringing clarity to the concept. In: Bakker, A.B. dan Leiter, M.P., editor. Work engement: a handbook of essential theory and research. New York: Psychology Press: 10-24.

Schaufeli, W.B., Bakker, A.B., (2003). UWES (Utrecht Work Engagement Scale Preliminary Manual) Version 1. :5-6. Domplein: Utrecht University, Occupational Health Psychology Unit.

Schaufeli, W.B. (2013). What is engagement? In C. Truss, K. Alfes, R. Delbridge, A. Shantz, \& E. Soane, Employee Engagement in Theory and Practice. London: Routledge.

Shimazu, A., Miyanaka, D., \& Scaufeli, W.B. (2010). Work Engagement from a cultural perspective. In: Albrecht, S., editor. Handbook of employee engagement perspectives, issues, researches and practices. USA: Edward Elar.

Smith, G.R., \& Markwick, C. (2009). Employee Engagement: A Review of Current Thinking. United Kingdom: Institute for Employee Studies.

Sugiyono. (2014). Metode Penelitian Kombinasi (Mixed Methods). Bandung: Alfabeta.

Suwarjo. (2006). Pengembangan SDM Melalui Konseling di Dunia Industri dan Tantangan Globalisasi. Paradigma, 1(1).

Trinrud, P. J. (2015). Constructing a Nomological Network of Work Engagement: An Examination of the Relationships between Work Engagement, Burnout, Job Satisfaction, Organizational Commitment, Job Stress, Workaholism, Personality, and Personal Affect (Tesis dipublikasikan). The Chicago School of Professional Psychology. Chicago.

Utama, M. S. (2016). Buku Ajar Aplikasi Analisis Kuantitatif untuk Ekonomi dan Bisnis. Denpasar: CV. Sastra Utama.
Yeh, C. M. (2013). Tourism involvement, work engagement and job satisfaction among frontline hotel employees. Annals of Tourism Research, 42, 214-239 


\section{LAMPIRAN}

Tabel 1

Deskripsi Data Penelitian

\begin{tabular}{cccccccccc}
\hline $\begin{array}{c}\text { Variabel } \\
\text { Penelitian }\end{array}$ & $\begin{array}{c}\text { Mean } \\
\text { Teoretis Empiris }\end{array}$ & $\begin{array}{c}\text { Standar } \\
\text { Deviasi } \\
\text { Teoretis }\end{array}$ & $\begin{array}{c}\text { Standar } \\
\text { Deviasi } \\
\text { Empiris }\end{array}$ & Xmin Xmax & $\begin{array}{c}\text { Sebaran } \\
\text { Teoretis }\end{array}$ & $\begin{array}{c}\text { Sebaran } \\
\text { Empiris }\end{array}$ & $\begin{array}{c}T \\
\text { (sig.) }\end{array}$ \\
\hline Kepuasan Kerja & 37,5 & 51,78 & 7,5 & 4,069 & 41 & 59 & $15-60$ & $41-59$ & $\begin{array}{c}136,469 \\
(0,000)\end{array}$ \\
\hline $\begin{array}{c}\text { Keadilan } \\
\text { Organisasional }\end{array}$ & 45 & 62,08 & 9 & 5,065 & 48 & 72 & $18-72$ & $48-72$ & $\begin{array}{c}131,441 \\
(0,000)\end{array}$ \\
\hline $\begin{array}{c}\text { Keterikatan } \\
\text { Kerja }\end{array}$ & 52,5 & 74,62 & 10,5 & 5,261 & 58 & 84 & $21-84$ & $58-84$ & $\begin{array}{c}152,100 \\
(0,000)\end{array}$ \\
\hline
\end{tabular}

Tabel 2

Hasil Uji Normalitas Data Penelitian

\begin{tabular}{cccc}
\hline Variabel & $\begin{array}{c}\text { Kolmogorov- } \\
\text { Smirnov }\end{array}$ & Sig. & Kesimpulan \\
\hline Kepuasan kerja & 1,149 & 0,143 & Data Normal \\
Keadilan Organisasional & 1,166 & 0,132 & Data Normal \\
Keterikatan Kerja & 0,878 & 0,423 & Data Normal \\
\hline
\end{tabular}

Tabel 3

Hasil Uji Linearitas Data Penelitian

\begin{tabular}{cccc}
\hline Variabel & Linearity & $\begin{array}{c}\text { Deviation from } \\
\text { Linearity }\end{array}$ & Kesimpulan \\
\hline $\begin{array}{c}\text { Kepuasan Kerja } \\
\text { Keterikatan Keja }\end{array}$ & 0,000 & 0,125 & Data Linear \\
$\begin{array}{c}\text { Keadilan Organisasional } \\
\text { Keterikatan Kerja }\end{array}$ & 0,000 & 0,442 & Data Linear \\
\hline
\end{tabular}

Tabel 4

Hasil Uji Multikolenieritas Data Penelitian

\begin{tabular}{cccc}
\hline Variabel & Tolerance & VIF & Kesimpulan \\
\hline Kepuasan Kerja & 0,361 & 2,769 & $\begin{array}{c}\text { Tidak terjadi } \\
\text { multikolinearitas }\end{array}$ \\
Keadilan Organisasional & 0,361 & 2,769 & $\begin{array}{c}\text { Tidak terjadi } \\
\text { multikolinearitas }\end{array}$ \\
\hline
\end{tabular}


Tabel 5

Hasil Uji Heteroskedastisitas Data Penelitian

\begin{tabular}{|c|c|c|c|c|c|c|}
\hline \multirow[t]{2}{*}{ Variabel } & \multicolumn{2}{|c|}{$\begin{array}{c}\text { Unstandardized } \\
\text { Coefficients }\end{array}$} & \multirow{2}{*}{$\begin{array}{c}\text { Standardized } \\
\text { Coefficients } \\
\text { (Beta) }\end{array}$} & \multirow[t]{2}{*}{$T$} & \multirow[t]{2}{*}{ Sig. } & \multirow[t]{2}{*}{ Kesimpulan } \\
\hline & B & $\begin{array}{c}\text { Std. } \\
\text { Error }\end{array}$ & & & & \\
\hline Kepuasan Kerja & 0,064 & 0,072 & 0,136 & 0,881 & 0,380 & $\begin{array}{c}\text { Tidak terjadi } \\
\text { heteroskedastisitas }\end{array}$ \\
\hline $\begin{array}{c}\text { Keadilan } \\
\text { Organisasional }\end{array}$ & $-0,110$ & 0,058 & $-0,291$ & $-1,888$ & 0,062 & $\begin{array}{c}\text { Tidak terjadi } \\
\text { heteroskedastisitas }\end{array}$ \\
\hline
\end{tabular}

Tabel 6

Uji Regresi Berganda Signifikansi Nilai F

\begin{tabular}{cccccc}
\hline & Sum of Squares & df & Mean Square & F & Sig. \\
\hline Regression & 2128,594 & 2 & 1064,297 & 116,116 & 0,000 \\
Residual & 1026,571 & 112 & 9,166 & & \\
Total & 3155,165 & 114 & & & \\
\hline
\end{tabular}

Tabel 7

Besarnya Pengaruh Variabel Bebas terhadap Variabel Terikat

\begin{tabular}{cccc}
\hline $\mathbf{R}$ & $\boldsymbol{R}$ Square & Adjusted $\boldsymbol{R}$ Square & $\begin{array}{c}\text { Std. Error of the } \\
\text { Estimate }\end{array}$ \\
\hline 0,821 & 0,675 & 0,669 & 3,0275 \\
\hline
\end{tabular}

Tabel 8

Hasil Uji Regresi Berganda Nilai Koefisien Beta dan Nilai t Variabel Kepuasan Kerja dan Keadilan Organisasional terhadap Keterikatan Kerja

\begin{tabular}{cccccc}
\hline Variabel & \multicolumn{2}{c}{$\begin{array}{c}\text { Unstandardized } \\
\text { Coefficients }\end{array}$} & $\begin{array}{c}\text { Standardized } \\
\text { Coefficients } \\
\text { (Beta) }\end{array}$ & $\boldsymbol{T}$ & Sig. \\
\cline { 2 - 3 } & $\mathbf{B}$ & Std. Error & & & \\
\hline (Constant) & 17,964 & 3,751 & & 4,789 & 0,000 \\
Kepuasan Kerja & 0,469 & 0,116 & 0,363 & 4,045 & 0,000 \\
$\begin{array}{c}\text { Keadilan } \\
\text { Organisasional }\end{array}$ & 0,521 & 0,093 & 0,502 & 5,596 & 0,000 \\
\hline
\end{tabular}


Tabel 9

Rangkuman Hasil Uji Hipotesis Penelitian

\begin{tabular}{|c|c|c|}
\hline No & Hipotesis & Hasil \\
\hline 1. & $\begin{array}{l}\text { Hipotesis Mayor: } \\
\text { Terdapat pengaruh signifikan antara kepuasan kerja dan } \\
\text { keadilan organisasional terhadap keterikatan kerja pada } \\
\text { karyawan Hotel Swasta X di Bali. }\end{array}$ & Diterima \\
\hline 2. $\quad$ a. & $\begin{array}{l}\text { Hipotesis Minor 1: } \\
\text { Terdapat pengaruh signifikan antara kepuasan kerja } \\
\text { terhadap keterikatan kerja pada karyawan Hotel Swasta X } \\
\text { di Bali. }\end{array}$ & Diterima \\
\hline b. & $\begin{array}{l}\text { Hipotesis Minor 2: } \\
\text { Terdapat pengaruh signifikan antara keadilan } \\
\text { organisasional terhadap keterikatan kerja pada karyawan } \\
\text { Hotel Swasta X di Bali. }\end{array}$ & Diterima \\
\hline
\end{tabular}

